\title{
The Role of Wikipedia in Providing Information on Coronavirus to Societies during the COVID-19 Pandemic
}

\author{
Adem Doğaner ${ }^{1}$ \\ ${ }^{1}$ Department of Biostatistics and Medical Informatics, Faculty of Medicine, Kahramanmaras Sutcu Imam University, \\ Kahramanmaras, Turkey
}

Received: 18 August 2020, Accepted: 14 November 2020, Published online: 31 December 2020

(C) Ordu University Institute of Health Sciences, Turkey, 2020

\begin{abstract}
Objective: The coronavirus, which had first appeared in late 2019, turned into a pandemic spreading all over the world in a short time. People used internet resources to get information during the pandemic process. Wikipedia is one of the popular sources of internet preferred for accessing information in diseases and previous outbreaks. This study, the use of Wikipedia as an internet source in the coronavirus pandemic process was evaluated. The societies access to the articles on Wikipedia has been analyzed in detail.

Methods: In the study, among the articles related to coronavirus on Wikipedia, the articles with a high number of views, which are displayed between January 20, 2020, and May 20, 2020, containing information in all languages were determined. 4 articles with the highest number of views matching these items were selected. These articles were evaluated in terms of views and updates. Searched topics on Wikipedia by societies during to pandemic process were determined.

Results: The number of Wikipedia searches in search engines increased significantly in the period of 20 January 2020 - 20 May 2020 compared to the period of 20 January 2019 - 20 May 2019 ( $<<0.001$ ). During the Coronavirus pandemic, "Wikipedia" was searched more in search engines. 4 articles reached over 130 million page views in total. Societies have researched past outbreaks and measures against coronavirus on Wikipedia.

Conclusion: Wikipedia has been an important source of internet for societies during the coronavirus pandemic process. Wikipedia data can be applied to predicting and modeling trends in societies.

Key words: Coronavirus, Wikipedia, Information, Internet.
\end{abstract}

Suggested Citation: Doganer A. The Role of Wikipedia in Providing Information on Coronavirus to Societies during the COVID19 Pandemic. Middle Black Sea Journal of Health Science, 2020; 6(3):316-324.

Address for correspondence/reprints:

Adem Doğaner

Telephone number: +90 (507) 3772380

ORCID-ID 0000-0002-0270-9350

E-mail: adem_doganer@hotmail.com
DOI: $\quad 10.19127 / \mathrm{mbsjohs} .781930$ 


\section{Introduction}

In late December 2019, a new case of coronavirus, which can be transmitted to humans in Wuhan, China, was reported (Chen et al., 2020). The new Coronavirus spread rapidly among humans. Coronavirus was detected in many people within a short time period in Wuhan. In late January, coronavirus cases were reported in many parts of China. Cases of coronavirus were reported in other surrounding countries. Coronavirus spread to distant countries in a short time. The World Health Organization (WHO) declared an "emergency" for the new coronavirus (2019-nCov) on January 30, 2020 (Sohrabi et al., 2020). Coronavirus spread to many countries in the world in February. WHO named the new disease COVID-19 (WHO, 2020). Coronavirus was observed in many countries in Europe, America, and Africa. The speed of the coronavirus spread is quite high. Coronavirus spread to many countries of the world in March. WHO announced the COVID-19 outbreak as a pandemic on 11 March (WHO, 2020). As of May 20, approximately 5,085,000 cases and 329,000 deaths have been reported worldwide (Worldometers, 2020).

The coronavirus outbreak affected the whole world in a short time. Pandemic has been the most important agenda topic worldwide. Coronavirus caused great anxiety and panic. Country governments implemented different measures to prevent the spread of coronavirus. Country administrations carried out many applications such as quarantine implementation, curfew, travel restriction, continuing education of students online, postponing sports, and organizations. Apart from the social effects of the coronavirus pandemic in society, there were also psychological effects (Roy et al., 2020).

Pandemics are special situations, which societies rarely experience within a century. Therefore, societies do not have experience against pandemics. Societies aren't acquainted with the new coronavirus. Societies needed information to fight against coronavirus pandemic. Societies met their information needs about coronavirus from different sources.

Providing individual measures in terms of public health is at the forefront of the main preventive practices. Access to valid information resources in all societies is important for individual measures to be taken. The Internet has created a powerful alternative to traditional information resources such as $\mathrm{TV}$, radio, and newspaper in terms of providing access to information in the society. The Internet has provided quick access to information. Stack of information on a large scale has come into being on the internet. Not all of the information on the internet environment can be reliable and accurate. It is possible to reach the desired information in every field with the internet. The Internet has been one of the most influential resources of information in the 21st century. Wikipedia is an internet encyclopedia with open access, the content of which is developed by users and which contains information about many articles (http://wikipedia.org). Wikipedia provides information to people in many languages. There are millions of articles on Wikipedia (2020). Wikipedia is an internet encyclopedia that is constantly growing and updated by users. Over time, Wikipedia has become a powerful source of information for users (Viegas et al., 2020).

\section{Related Works}

Many websites contain reliable and accurate information in the field of health. There is a lot of information about health on Wikipedia. There has been a lot of research on the reliability and usability of the information available on Wikipedia. In their study, Del Valle et al. (2018) compared the information on diseases on Wikipedia articles with the information on Pubmed. As a result, they stated that the information on Wikipedia is similar to the information in PubMed. They stated that Wikipedia is a reliable source of information on diseases. Wikipedia is one of the frequently used information sources for information about diseases. Brigo et al. (2018) investigated how multiple sclerosis patients learned about the disease from Wikipedia. Moccia et al. (2016) stated that Wikipedia is one of the information resources that multiple sclerosis patients frequently access. Brigo et al. (2018) conducted research to obtain information about the attitudes and behaviors of epilepsy patients in Italy while accessing information. Jabaley et al. (2019) evaluated articles on asthma on Wikipedia to test awareness about asthma in their studies. Wikipedia is preferred as a source of information on issues related to epidemics. In their studies, Al tamime et al. (2018), evaluated the change in the number of articles and updates on Wikipedia about epidemics. In their studies, Priedhorsky et al. (2017), made an evaluation through Wikipedia to see the effects of the diseases that cause a global epidemic in society.

In this study, detailed research was conducted on the use of Wikipedia as a source of internet about coronavirus. Articles related to coronavirus on Wikipedia were examined. People's access to information on coronavirus was evaluated on Wikipedia. 


\section{Methods}

In the study, Wikipedia's articles about coronavirus, which were displayed between January 20, 2020, and May 20, 2020, were taken into consideration. There are many articles about coronavirus on Wikipedia. Articles with the highest number of pageviews and information about coronavirus in multiple languages are included in the study. The articles "Coronavirus," "Severe acute respiratory syndrome coronavirus 2", "COVID-19 pandemic" and "Coronavirus Disease 2019" on Wikipedia were evaluated within the scope of the study. The distribution of references in the articles is examined by their categories. Table 1 shows the categories of references. Pageviews of the articles for accessing information sources were taken into consideration. In the evaluation of the up-to-dateness of the information, the update numbers of the articles were taken into consideration. In terms of determining what kind of information societies access most, the pageviews of the articles by languages were compared. The data set of the study was obtained from Wikipedia's pageviews analysis tool (https://pageviews.toolforge.org). Article update numbers and article views were obtained from the pageviews analysis tool (https://pageviews.toolforge.org). Search rates of Wikipedia's on search engines are accessed through the Google trends tool (Google Trends, 2020).

\section{Statistical Analysis}

The conformity of the data to the normal distribution was examined with the KolmogorovSmirnov test. A paired t-test was used for repeated measurement in variables with a normal distribution. The statistical significance was accepted as $\mathrm{p}<0.05$. The data were evaluated with IBM SPSS for Windows version 22 (IBM SPSS for Windows version 22, IBM Corporation, Armonk, New York, United States).

\section{Results}

People researched information from different sources during the coronavirus pandemic process. In this process, the search rates of 20 January 2020 - 20 May 2020 and 20 January 2019 - 20 May 2019 were compared to determine the change on Wikipedia search rates on internet search engines. Comparison results are given in table 1. Between January 20, 2020, and May 20, 2020, Wikipedia search rates in internet search engines increased significantly $(p<0.001)$. Figure 1 shows the change in search rates over time. As of April, in the pandemic process, there was a significant increase on Wikipedia search rates on internet search engine compared to the previous year.

Table 1. Comparison of search rates of Wikipedia on internet search engines

\begin{tabular}{llll}
\hline & $\begin{array}{l}\text { 20 January 2019 } \\
\text { - 20 May 2019 }\end{array}$ & $\begin{array}{l}\text { 20 January 2020 } \\
\text { - 20 May 2020 }\end{array}$ & p \\
\hline $\begin{array}{l}\text { Search Ratio of Wikipedia } \\
\text { on Search Engine, Mean } \pm \text { SD }\end{array}$ & $73,90 \pm 4,43$ & $76,33 \pm 4,76$ & p $<\mathbf{0 . 0 0 1 *}$ \\
\hline
\end{tabular}

Paired t test; $\alpha: 0.05$; ${ }^{*}$ Statistical significance

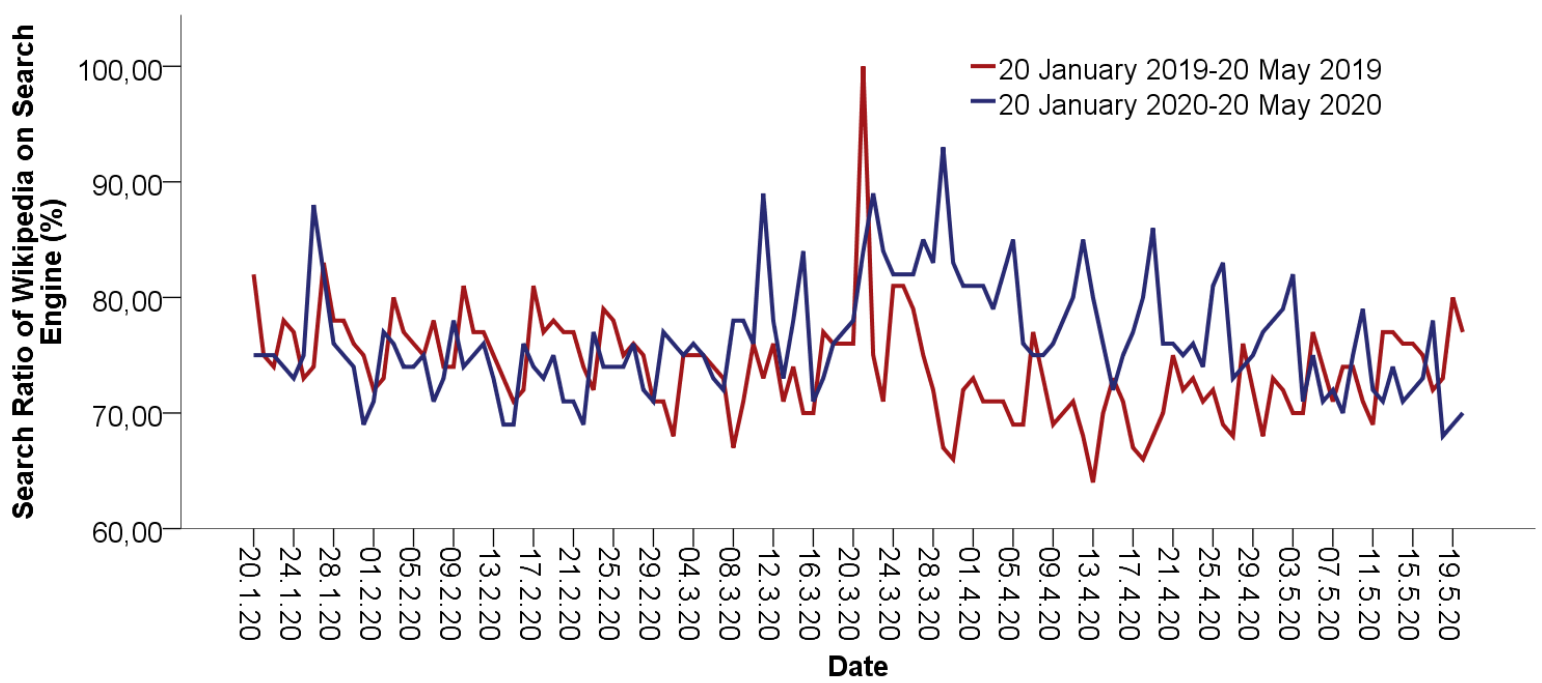

Figure 1. Search rates of Wikipedia on internet search engines according to time 
Table 2. Updating article titles on Wikipedia according to time

\begin{tabular}{|c|c|c|c|c|}
\hline \multirow[t]{2}{*}{ Date } & \multicolumn{4}{|c|}{ Article titles on Wikipedia } \\
\hline & Coronavirus & $\begin{array}{l}\text { Severe acute } \\
\text { respiratory } \\
\text { syndrome } \\
\text { coronavirus } 2\end{array}$ & $\begin{array}{l}\text { Coronavirus } \\
\text { Disease } 2019\end{array}$ & COVID-19 pandemic \\
\hline $\begin{array}{l}\text { January } \\
2020\end{array}$ & Coronavirus & $\begin{array}{l}\text { Novel coronavirus } \\
(2019-\mathrm{nCoV})\end{array}$ & - & $\begin{array}{l}2019-20 \text { outbreak of novel } \\
\text { coronavirus (2019-nCoV) }\end{array}$ \\
\hline $\begin{array}{l}\text { February } \\
2020\end{array}$ & Coronavirus & $\begin{array}{l}\text { Novel coronavirus } \\
(2019-n \mathrm{CoV})\end{array}$ & $\begin{array}{l}\text { Coronavirus disease } \\
2019\end{array}$ & $\begin{array}{l}2019-20 \text { coronavirus } \\
\text { outbreak }\end{array}$ \\
\hline $\begin{array}{l}\text { March } \\
2020\end{array}$ & Coronavirus & $\begin{array}{l}\text { Severe acute } \\
\text { respiratory syndrome } \\
\text { coronavirus } 2\end{array}$ & $\begin{array}{l}\text { Coronavirus disease } \\
2019\end{array}$ & $\begin{array}{l}\text { 2019-20 coronavirus } \\
\text { pandemic }\end{array}$ \\
\hline $\begin{array}{l}\text { April } \\
2020\end{array}$ & Coronavirus & $\begin{array}{l}\text { Severe acute } \\
\text { respiratory syndrome } \\
\text { coronavirus } 2\end{array}$ & $\begin{array}{l}\text { Coronavirus disease } \\
2019\end{array}$ & $\begin{array}{l}\text { 2019-20 coronavirus } \\
\text { pandemic }\end{array}$ \\
\hline $\begin{array}{l}\text { 1-20 May } \\
2020\end{array}$ & Coronavirus & $\begin{array}{l}\text { Severe acute } \\
\text { respiratory syndrome } \\
\text { coronavirus } 2\end{array}$ & $\begin{array}{l}\text { Coronavirus disease } \\
2019\end{array}$ & COVID-19 pandemic \\
\hline
\end{tabular}

The content of articles related to coronavirus on Wikipedia was updated as new information about coronavirus came out. Article titles related to coronavirus on Wikipedia also changed as the information was updated. The change and updating of the article titles by months are given in table 2 . During the Coronavirus pandemic process, new information was continuously obtained. The change in the number of times the article contents of Wikipedia are updated over time is shown in figure 2. The article that received the most updates was
"COVID-19 Pandemic". The change in the number of updates in the articles revealed that new information about the pandemic was obtained. New information on coronavirus was obtained mostly in late January and in March. The number of times the articles about coronavirus on Wikipedia are displayed according to time is shown in Figure 3. It was observed that the most viewed article was "Coronavirus". The total number of updates and pageviews of the articles are given in table 3.

Table 3. Views and updated numbers of articles about Coronavirus on Wikipedia

\begin{tabular}{llll}
\hline & $\begin{array}{l}\text { Numbers } \\
\text { View }\end{array}$ & $\begin{array}{l}\text { of } \\
\text { Update }\end{array}$ & of \\
\hline Coronavirus & 50.929 .853 & 1.001 \\
COVID-19 pandemic & 37.434 .046 & 20.323 \\
Coronavirus Disease 2019 & 28.357 .359 & 4.708 \\
Severe acute respiratory syndrome coronavirus 2 & 15.591 .762 & 3.223 \\
\hline
\end{tabular}




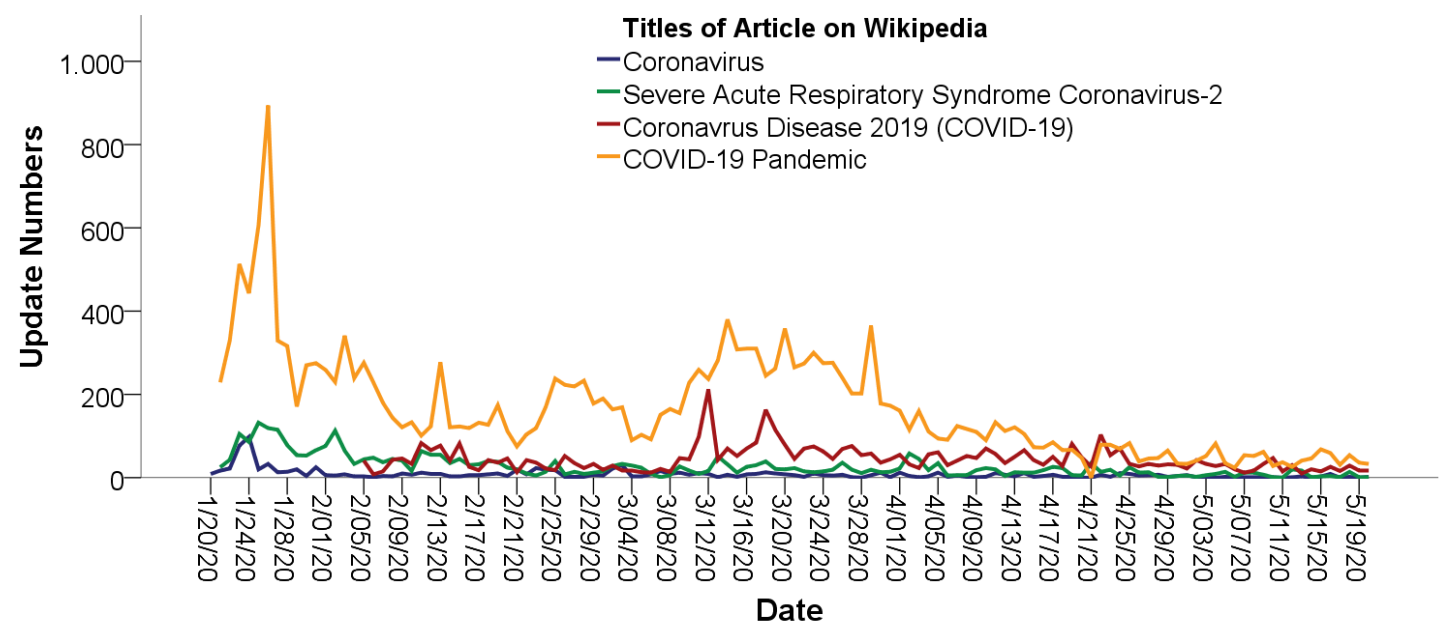

Figure 2. Update numbers of articles on Wikipedia according to time

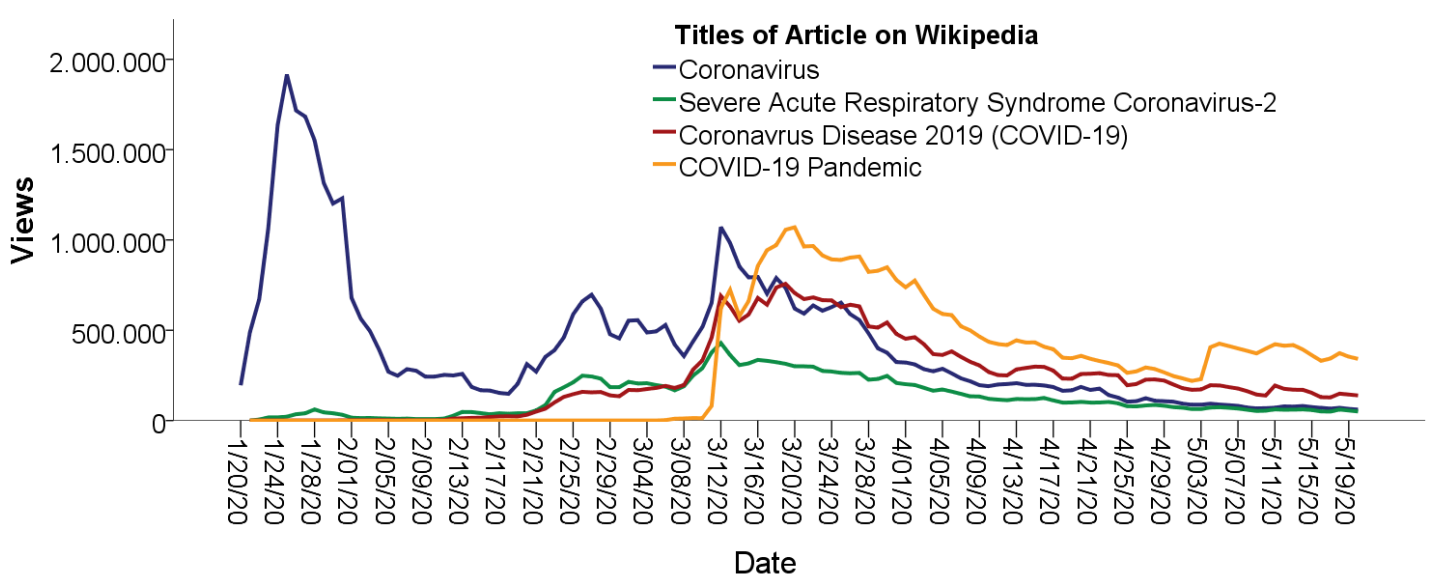

Figure 3. View numbers of articles on Wikipedia according to time

The pageviews of Wikipedia says a lot about people's access to information. The spelling languages of the items displayed on Wikipedia provide an idea about the access of societies to information. The number of pageviews in different languages on 4 articles on Wikipedia between January 20, 2020, and May 20, 2020, were evaluated. The most frequently viewed language is English. In terms of pageviews, Spanish, Russian, German, French, and Chinese are the most viewed languages after English. The "Coronavirus" article was viewed the most in societies using English, French, Polish and Portuguese languages. In societies using Spanish, German, Chinese, Italian, and Russian languages, the article "COVID-19 pandemic" was displayed mostly. In societies using the Japanese language, "Severe acute respiratory syndrome coronavirus 2 " article was displayed mostly. View numbers of articles on Wikipedia according to languages are displayed in Figure 4.
The most researched title of pages related to the Coronavirus on Wikipedia are determined for different languages between January 20, 2020 and May 20, 2020. The most researched title of pages differs according to the societies. Societies have generally researched past outbreaks on Wikipedia in order to understand coronavirus. In addition, societies have examined the measures to be taken against coronavirus on Wikipedia. Most searched title of pages related to Coronavirus on Wikipedia according to languages are given in table 4.

In combating the COVID-19 pandemic, it is very important for people to comply with the measures taken against the Coronavirus. The use of masks, social distance and hand hygiene are the most important measures for Coronavirus. In Figure 5, the numbers of views for masks, social distance and hand washing titles of pages on Wikipedia is showed. It is observed that societies are mostly researching the use of masks. 


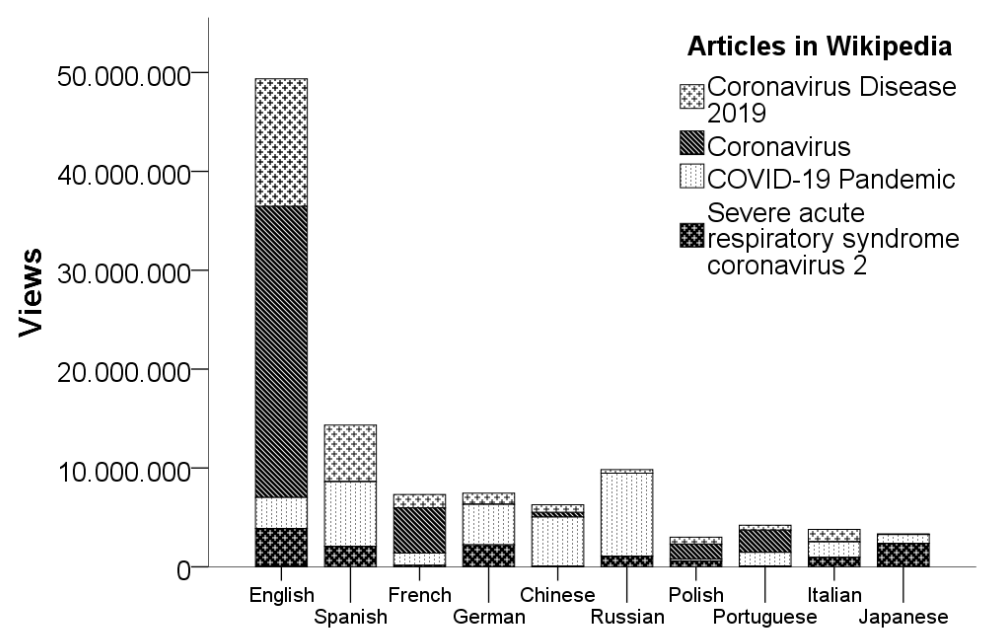

Figure 4. View numbers of articles on Wikipedia according to languages

Table 4. Most searched titles of Article related to Coronavirus on Wikipedia according to languages

\begin{tabular}{|c|c|c|c|c|c|}
\hline Languages & Titles of Article & n Wikipedia & & & \\
\hline English & $\begin{array}{l}\text { Deaths } \\
\text { in } 2020\end{array}$ & $\begin{array}{l}\text { Spanish } \\
\text { Flu }\end{array}$ & WHO & $\begin{array}{l}\text { COVID-19 } \\
\text { Testing }\end{array}$ & Swine Influenza \\
\hline Spanish & Quarantine & State of alarm & N95 & $\begin{array}{ll}1918 & \text { flu } \\
\text { pandemic }\end{array}$ & Wuhan \\
\hline French & FFP Mask & 1918 Influenza & Ebola & $\begin{array}{l}\text { Body } \\
\text { temperature }\end{array}$ & Malaria \\
\hline German & Paracetamol & Ebola & $\begin{array}{l}\text { Short } \\
\text { time work }\end{array}$ & Hantavirus & $\begin{array}{l}\text { Body } \\
\text { temperature }\end{array}$ \\
\hline Chinese & Etanol & Italy & WHO & Black Death & H1N1 Influenza \\
\hline Russian & Pneumonia & $\begin{array}{l}\text { Black } \\
\text { Death }\end{array}$ & $\begin{array}{l}\text { BCG } \\
\text { Vaccine }\end{array}$ & Hand antiseptic & Mask \\
\hline Polish & $\begin{array}{ll}\begin{array}{l}\text { State } \\
\text { emergency }\end{array} & \text { of } \\
\end{array}$ & Iran & Cholera & China & SARS \\
\hline Portuguese & $\begin{array}{l}\text { Bubonic } \\
\text { plague }\end{array}$ & $\begin{array}{l}70 \% \\
\text { Alcohol }\end{array}$ & Asymptomatic & Avian Influeza & WHO \\
\hline Italian & $\begin{array}{l}\text { Herd } \\
\text { immunity }\end{array}$ & Lombardia & Infection & Wuhan & Ebola \\
\hline Japanese & SARS & MERS & $\begin{array}{l}\text { Spanish } \\
\text { Flu }\end{array}$ & BCG Vaccine & $\begin{array}{ll}\begin{array}{l}\text { State } \\
\text { emergency }\end{array} & \text { of } \\
\end{array}$ \\
\hline
\end{tabular}

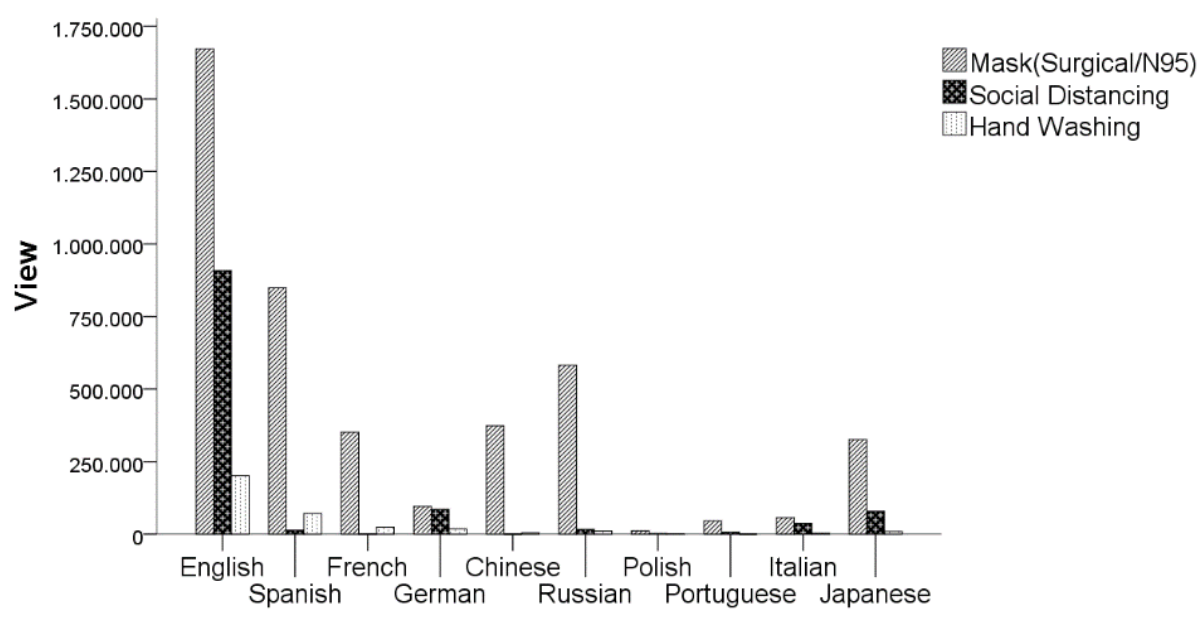

Figure 5. View numbers of articles on coronavirus measures according to languages 


\section{Discussion}

Coronavirus pandemic caused great anxiety in societies. One of the biggest reasons for this anxiety was that people had little information about the coronavirus. Humans needed more information about the disease to take action against coronavirus. During this process, people often used internet sources to learn about coronavirus. Many websites contain information about coronavirus. People used more internet sources during the pandemic process than in previous years. Khatri et al. (2020) conducted a research on the use of YouTube as a source of information during the coronavirus pandemic process. They stated that Youtube had higher viewing rates during the coronavirus pandemic than the previous outbreaks. Wikipedia is one of the popular websites containing information about coronavirus. In our study, it was determined that Wikipedia was displayed more in the coronavirus pandemic period compared to previous years. This result we obtained supports the literature. Wikipedia is one of the preferred sources of information during the pandemic.

The change of article titles on Wikipedia over time was examined. The articles "Coronavirus" and "Coronavirus Disease 2019" on Wikipedia did not change over time. The titles "COVID-19 pandemic" and "Severe acute respiratory syndrome coronavirus 2 " on Wikipedia changed over time. The main reason for the change of these titles on Wikipedia is the announcement of the pandemic in March. In addition to the change of article titles on Wikipedia, the article contents are also frequently updated. Georgescu et al. (2013) stated that on Wikipedia, many users can update the content of the articles. The change in the number of updates is an important sign to show that there are new findings about the article, that the content has been improved and that new information has been obtained. The findings of our study showed that there were many updates in four articles on Wikipedia. The most frequent updates were made in the article "COVID-19 pandemic". A lot of new information was obtained during the pandemic. The periods, in which the most information updates are made, are in the middle of March and as of the second half of January. The first case was reported in the United States on January 20 (Omer et al., 2020). The first cases were reported in Europe on 24 January (Stoecklin et al., 2020). WHO announced coronavirus pandemic worldwide on 11 March Cucinotta and Vanelli, 2020).

The number of pageviews on the websites is considered a behavioral measure of the search for information in society (Tausczik et al., 2012). In the study, the number of pageviews on Wikipedia was determined to show the public's search for information about coronavirus pandemic. The highest number of pageviews was observed in the article "Coronavirus" (number of pageviews: 50.929.853). In other articles, it was observed that the number of pageviews was quite high (number of pageviews range: 37.434.046-15.591.762). Coronavirus articles have reached very high page views in a short time. These findings show that societies are intensely seeking information about coronavirus.

The number of page views of the article "Coronavirus" increased significantly in the second half of January. The reason for this is that the coronavirus outbreak spread to America and Europe in the second half of January. Another period, in which the number of page views increased in midMarch. In March, WHO announced the coronavirus as a global pandemic (Cucinotta and Vanelli, 2020). At the same time, the coronavirus outbreak spread to many countries around the world in March. The Coronavirus outbreak became one of the most important issues in the world in March. In their study, Tizzoni et al. (2020) investigated the number of Wikipedia page views of articles related to the Zika virus. The number of page views of Coronavirus articles was higher than the number of page views of Zika virus articles. The Coronavirus outbreak has led to more information seeking in societies than happened in the world before.

Examining the information researched by societies is an important criterion in determining the behavioral differences of societies. In our study, it is observed that societies using English, French, Polish, and Portuguese language mostly view the article "Coronavirus". The article "Coronavirus" contains general information about the virus. Societies using Spanish, Russian, German, and Chinese languages mostly viewed the article "COVID-19 pandemic". The article "COVID-19 Pandemic" gives information about the developments during the pandemic. Societies using the Italian language mostly viewed the article "Coronavirus Disease 2019". The article "Coronavirus Disease 2019" contains information about the disease. Finally, societies using the Japanese language mostly viewed the article "Severe acute respiratory syndrome coronavirus $2 "$. The article "Severe acute respiratory syndrome coronavirus 2" contains information about the biological structure of the virus.

During the pandemic process, the topics related to the coronavirus most viewed on Wikipedia have been specified according to Societies. Societies using the Russian language have often sought measures against 
coronavirus. Other societies have frequently investigated past outbreaks, WHO, the social effects of the pandemic, and similar viruses. Societies have researched measures against coronavirus on Wikipedia. Societies have researched measures against coronavirus on Wikipedia.

\section{Limitations}

There are some limitations to this study. Wikipedia is a dynamic internet encyclopedia that is constantly updated and displayed. The data and information on Wikipedia can change constantly. Coronavirus pandemic is still ongoing. Therefore, the findings we obtained from the study cover between January 20, 2020, and May 20, 2020. Since Coronavirus emerged since January 2020, there was no chance to compare the study findings with previous years. Similarly, it could not be compared to a different outbreak or disease. There are many articles about coronavirus on Wikipedia. However, many articles were excluded because they were written only in a specific language or the scope of the article was for a specific region. Quantitative methods could not be evaluated because there is no quantitative measurement tool for the title of articles on Wikipedia. In terms of some languages, data cannot be found in every articles on Wikipedia's pageview analysis tool (https://pageviews.toolforge.org). Therefore, some languages could not be included in the study. Wikipedia's pageview analysis tool does not provide data on for country. For this reason, the languages used by societies were included in the study.

\section{Conclusion}

As a result, Wikipedia has been observed to be a frequently used source of internet that societies prefer to read during the coronavirus pandemic. Wikipedia has been identified as a popular source of internet for coronavirus. Wikipedia can provide information about trends in societies. Wikipedia can be applied to research based on prediction and modeling about societies should have more access to Wikipedia.
Ethics Committee Approval: We did not evaluate any human participants or animals in this study. Internet data that anyone can access were evaluated. Therefore, there was no need for approval of the ethics committee for this study.

Peer-review: Externally peer-reviewed.

Author Contributions: Concept -A.D; Design- A.D; Supervision- A.D; Materials- A.D; Data Collection and/or Processing- A.D; Analysis and/or Interpretation- A.D; Literature Review- A.D; Writing- A.D; Critical Review- A.D.

Conflict of Interest: No conflict of interest was declared by the author.

Financial Disclosure: The author declared that this study hasn't received no financial support.

\section{References}

Al Tamime R, Giordano R, Hall W. Observing burstiness in wikipedia articles during new disease outbreaks. In: WebSci 2018 - Proceedings of the 10th ACM Conference on Web Science. 2018. doi:10.1145/3201064.3201080.

Bernard Stoecklin S, Rolland P, Silue Y, Mailles A, Campese C, Simondon A, et al.; Investigation Team. First cases of coronavirus disease 2019 (COVID-19) in France: surveillance, investigations and control measures, January 2020. Euro Surveill. 2020 Feb;25(6):2000094. doi: 10.2807/1560-7917.ES.2020.25.6.2000094.

Brigo F, Lattanzi S, Bragazzi N, Nardone R, Moccia M, Lavorgna L. Why do people search Wikipedia for information on multiple sclerosis?. Mult Scler Relat Disord. 2018;20:210-214. doi:10.1016/j.msard.2018.02.001.

Brigo F, Lattanzi S, Tassi L, Giussani G, Italian Wikipedia and epilepsy: An infodemiological study of online information-seeking behavior. Epilepsy Behav. 2018;81:119-122. doi:10.1016/j.yebeh.2018.01.037.

Chen N, Zhou M, Dong X, Qu J, Gong F, Han Y, et al. Epidemiological and clinical characteristics of 99 cases of 2019 novel coronavirus pneumonia in Wuhan, China: a descriptive study. Lancet. 2020;395(10223):507-513. doi:10.1016/S01406736(20)30211-7.

Cucinotta D, Vanelli M. WHO Declares COVID-19 a Pandemic. Acta Biomed. 2020;91(1):157-160. doi:10.23750/abm.v91i1.9397.

Del Valle EPG, Garcia GL, Prieto Santamaria L, Zanin M, Ruiz EM, González AR. Evaluating Wikipedia as a Source of Information for Disease Understanding. In: Proceedings IEEE Symposium 
on Computer-Based Medical Systems. 2018. doi:10.1109/CBMS.2018.00076.

Georgescu M, Kanhabua N, Krause D, Nejdl W, Siersdorfer S. Extracting event-related information from article updates in Wikipedia. In: Lecture Notes in Computer Science (including subseries Lecture Notes in Artificial Intelligence and Lecture Notes in Bioinformatics). Springer, Berlin, Heidelberg. 2013. pp. 254-266.

Google Trends, 2020. Wikipedia. Available from URL

https://trends.google.com/trends/explore?geo=TR \&q=Wikipedia. Accessed 30 May 2020.

Jabaley CS, Groff RF, O'Reilly-Shah VN. Asthma information seeking via Wikipedia between 2015 and 2018: Implications for awareness promotion. American Journal of Respiratory and Critical Care Medicine. 2019. 199(4):531-3. doi: 10.1164/rccm.201809-1649LE.

Khatri P, Singh SR, Belani NK, Yeong YL, Lohan R, Lim YW, et al. YouTube as source of information on 2019 novel coronavirus outbreak: a cross sectional study of English and Mandarin content. Travel Med Infect Dis. 2020. 35:101636. doi: 10.1016/j.tmaid.2020.101636.

Moccia M, Carotenuto A, Massarelli M, Lanzillo R, Brescia Morra V. Can people with multiple sclerosis actually understand what they read in the Internet age? J Clin Neurosci. 2016. 1;25:167-8. doi:10.1016/j.jocn.2015.10.003.

Omer SB, Malani P, Del Rio C. The COVID-19 Pandemic in the US: A Clinical Update. JAMA Journal of the American Medical Association. 2020. doi:10.1001/jama.2020.5788.

Pageviews Analysis Tool, 2020. https://pageviews.toolforge.org. Accessed 25-30 May 2020.

Priedhorsky R, Osthus D, Daughton AR, Moran KR, Generous N, Fairchild G, et al. Measuring global disease with Wikipedia: Success, failure, and a research agenda. In: Proceedings of the ACM Conference on Computer Supported Cooperative Work, CSCW. 2017. doi:10.1145/2998181.2998183.

Roy D, Tripathy S, Kar SK, Sharma N, Verma SK, Kaushal V. Study of knowledge, attitude, anxiety $\&$ perceived mental healthcare need in Indian population during COVID-19 pandemic. Asian J Psychiatr. 2020. doi:10.1016/j.ajp.2020.102083.

Sohrabi C, Alsafi Z, O’Neill N, Khan M, Kerwan A, Al-Jabir A, et al. World Health Organization declares global emergency: A review of the 2019 novel coronavirus (COVID-19). International
Journal of Surgery. 2020. doi: 10.1016/j.ijsu.2020.02.034.

Tausczik Y, Faasse K, Pennebaker JW, Petrie KJ. Public Anxiety and Information Seeking Following the H1N1 Outbreak: Blogs, Newspaper Articles, and Wikipedia Visits. Health Commun. 2012. doi:10.1080/10410236.2011.571759.

Tizzoni M, Panisson A, Paolotti D, Cattuto C. The impact of news exposure on collective attention in the United States during the 2016 Zika epidemic. PLoS Comput Biol. 2020. doi:10.1371/journal.pcbi.1007633.

Viégas FB, Wattenberg M, Kriss J, Van Ham F. Talk before you type: Coordination in Wikipedia. In: Proceedings of the Annual Hawaii International Conference on System Sciences. 2007. doi: 10.1109/HICSS.2007.511.

Wikipedia, $2020 . \quad$ Wikipedia. https://en.wikipedia.org.

WHO. (2020), "WHO Director-General 's remarks at the media briefing on $2019-\mathrm{nCoV}$ on 11 February", WHO Director General's Statement.

World Health Organization (WHO). (2020), Coronavirus disease 2019 (COVID-19) situation report - 51. 2020 March 11. Available from URL https://www.who.int/docs/defaultsource/coronaviruse/situation-reports/20200311sitrep-51-covid-19.pdf?sfvrsn=1ba62e57_10. Accessed 24 May 2020.

Worldometers, 2020. COVID-19 Coronavirus Pandemic. Available from URL https://www.worldometers.info/coronavirus/\#cou ntries. Accessed 20 May 2020. 